\title{
Optimization of the Electrophoresis Tricine-SDS-PAGE for Simultaneous Detection of Protein and Peptide in Artisinal Cheese
}

\author{
Juliana de Oliveira Carneiro ${ }^{1}$, Marilia Penteado Stephan ${ }^{2}$, Izabela Miranda de Castro ${ }^{2}$, Ana Carolina Sampaio \\ Doria Chaves ${ }^{2}$, Alexsandro Araújo dos Santos ${ }^{2}$, Tatiana de Lima Azevedo ${ }^{2}$ and Maria Gabriela Bello Koblitz ${ }^{1}$ \\ 1. Laboratory of Biochemistry, Federal University of the State of Rio de Janeiro, Rio de Janeiro, Cep 22290-240, Brazil \\ 2. Laboratory of Biochemistry, Embrapa Food Technology, Rio de Janeiro, Cep 22210-085, Brazil
}

\begin{abstract}
The objective of this paper was to optimize an electrophoretic methodology (Tricine-SDS-PAGE) to monitor the degree of caseins hydrolysis during the maturation time of artisanal cheese. A cheaper and easier method was obtained using small samples and micro-quantities of reagents. Simultaneous detection of proteins and peptides (100 kDa to $1 \mathrm{kDa})$ in the same gel was another advantage of the method. Initially, protein extraction was performed with $2 \mathrm{mg}$ of lyophilized cheese dissolved in $1.0 \mathrm{~mL}$ of sample electrophoretic buffer for $1 \mathrm{~h}$ under stirring. After that, the Eppendorf tubes of the samples were kept at $-4{ }^{\circ} \mathrm{C}$ for $4 \mathrm{~h}$ with additional centrifugation at $5,433 \times g$ for $2 \mathrm{~min}$. This defatting process using centrifugation/refrigeration promoted a good separation of proteins and peptides from the fat layer. After this step, $30 \mu \mathrm{L}$ of the supernatant of the protein extracts was applied to the electrophoresis gel. The results revealed a clear image of protein and peptides in the polyacrylamide gels and allowed an excellent response of the distribution of casein bands $(\alpha, \beta$ and $\kappa)$ and the exposure peptide in cheese. The utilization of artisanal cheese as a pilot study of molecular protein analysis could be helpful for further correlation of the fingerprint of protein-peptide profile with taste quality.
\end{abstract}

Key words: Artisanal cheese, electrophoresis, maturation time, proteolysis.

\section{Introduction}

The stage of cheese maturation involves many physical, chemical and biochemical reactions. The time can vary from a few days to more than two years depending on the type of cheese. Proteolysis is the most complex and important primary event that occurs during cheese ripening and it plays a vital role in the development of texture and flavor. Hydrolysis of caseins leads to the formation of large and intermediate-sized peptides, which are degraded into smaller peptides by enzymes produced by starter culture and non-starter bacteria or fungi [1]. This will result in peptides of differentiated molecular mass as already described by studying artisanal cheeses using

Corresponding author: Marilia Penteado Stephan, DSc, research field: biochemistry. proteomic analysis [2]. It is important to emphasize that others authors [2] used a very expensive proteomic and peptidomic methodology of analysis as well as the laborious procedure of protein extraction. Many studies show the application of capillary electrophoresis, liquid chromatography coupled with Tandem mass-spectrometry (MS/MS), and ultra-performance liquid chromatography to study proteolysis in cheese [3]. It is very important to say that electrophoresis in gel of polyacrylamide is a simple technique that can be also used to study proteolysis of cheese. Three kinds of electrophoresis could be applied for this study, SDS-PAGE [4], Native PAGE [5] and Tricine-SDS-PAGE [6]. However, using only the procedure with Tricine-SDS-PAGE [6], it was possible to identify peptides with molecular weight up to $1 \mathrm{kDa}$. The 
objective of this work was to show the application of Tricine-SDS-PAGE electrophoresis technique with the modification of procedure method of sample preparation, which uses micro-quantities of samples and buffer. The simplicity of the defat step and protein extraction is also a new strategy.

\section{Materials and Methods}

The cheese samples were purchased from three different producers of the state of Minas Gerais in Brazil. Electrophoresis Tricine-SDS-PAGE [5] was utilized for identification of protein-peptide profiles of cheese maturated during two different times $(17 \mathrm{~d}$ and $60 \mathrm{~d})$. After freeze-drying, $2 \mathrm{mg}$ of crushed cheeses was solubilized during $1 \mathrm{~h}$ under agitation with electrophoretic buffer pH 6.8 with $4 \%$ SDS, $12 \%$ glycerol, $2 \%$ mercaptoetanol and $0.01 \%$ Coomassie blue G250, using Eppendorf tube. Two different extracts of protein and peptide extracts were obtained: with and without fat. The one with fat was applied directly in the electrophoresis. In order to obtain the protein-peptide extract without fat, the fatted extracted was kept under $-18{ }^{\circ} \mathrm{C}$ during $4 \mathrm{~h}$ and further centrifuged $5,433 \times g$ during $1 \mathrm{~min}$. The purified protein-peptide extract has been removed from the upper layer of fat with a micropipette.

\section{Results and Discussion}

All samples with fat, obtained from three different cheese producers at two different times of maturation (17 d and $60 \mathrm{~d}$ ), showed a gel with a spread staining (Fig. 1). This could be explained by the high amount of fat present in these cheese protein extracts. As a solution to solve this problem, additional steps in the methodology were included. Initially, the same procedure of obtaining the protein extract was utilized as following, $2 \mathrm{mg}$ of crushed and freeze-dried cheese was solubilized in electrophoretic buffer and submitted to vigorous agitation during $1 \mathrm{~h}$ at room temperature. The introduction of two steps in this procedure gave as a result a polyacrylamide gel showing a completely clear image, first by submitting

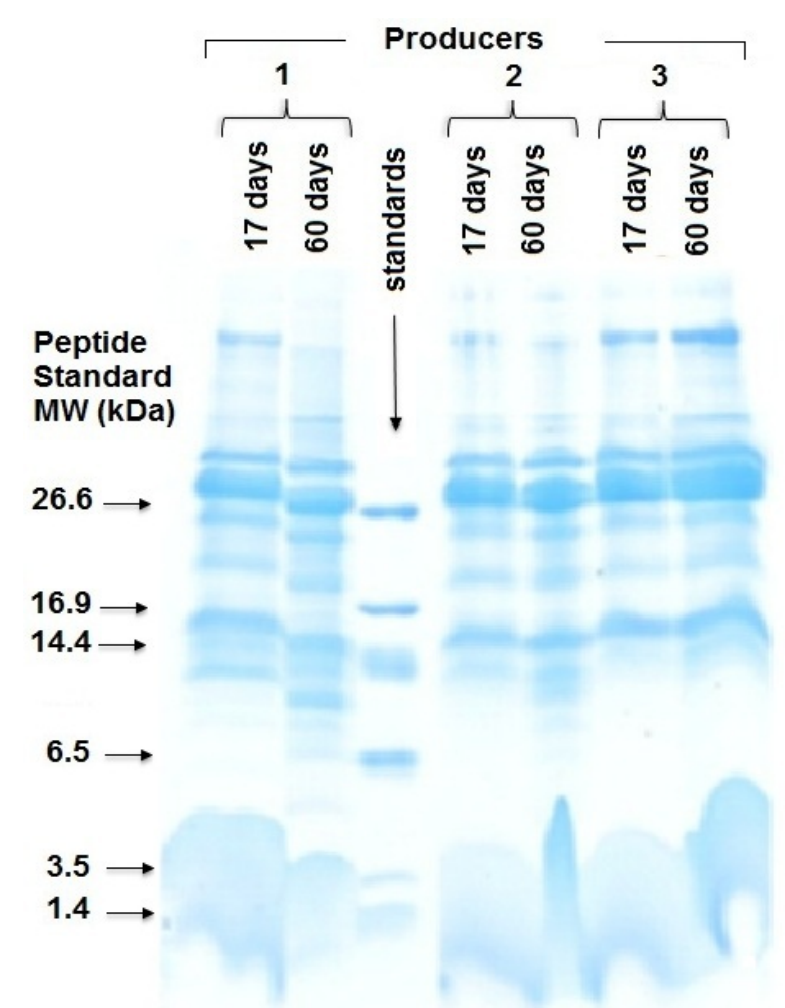

Fig. 1 Tricine-SDS-PAGE electrophoretic profiles of fatted protein-peptide extracts obtained from artisanal cheeses of three different producers (1, 2 and 3$)$. 
them to $1 \mathrm{~h}$ incubation at $-4^{\circ} \mathrm{C}$, in the same Eppendorf tubes of $2.0 \mathrm{~mL}$ and with further centrifugation at $5,433 \times g$, during $1 \mathrm{~min}$. The clear protein extract separated from small fat plates can be seen in the Eppendorf tubes for all cheeses of the three producers (Fig. 2). Recently, molecular studies involving cheese analysis have shown the use of laborious steps for sample purification as described for the analysis of a peptide $(3.5 \mathrm{kDa})$ by LC-MS/MS [7], while other works show the formation of peptides arising from cheese ripening by electrophoresis Urea-PAGE [8] or SDS-PAGE [9]. The association of Tricine-SDS-PAGE and the samples without fat shows the quality of this result and that the method has been optimized. The deffated extracts were applied in polyacrylamide gel electrophoresis Tricine-SDS-PAGE (concentrations of acrylamide of $16.5 \%, 10 \%$ and $4 \%$ were used, respectively, in the separating gel, spacing gel and application gel) and a gel with a clear aspect was obtained (Fig. 3). The results related to the cheese ripening process show different protein and peptide profiles among the three producers, probably due to the specific ripening conditions of each one. Genomic analysis, nuclear magnetic resonance (NMR) and immunochemical analysis are currently being used for proteolysis studies

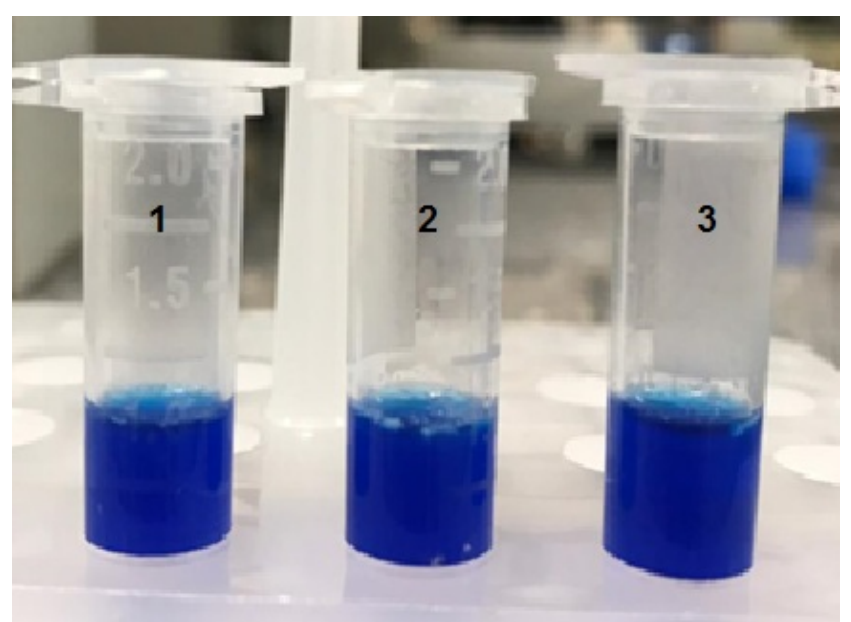

Fig. 2 Eppendorf tubes with the separation of fat layer from the protein-peptide extract of cheese from three different producers $(1,2$ and 3$)$.

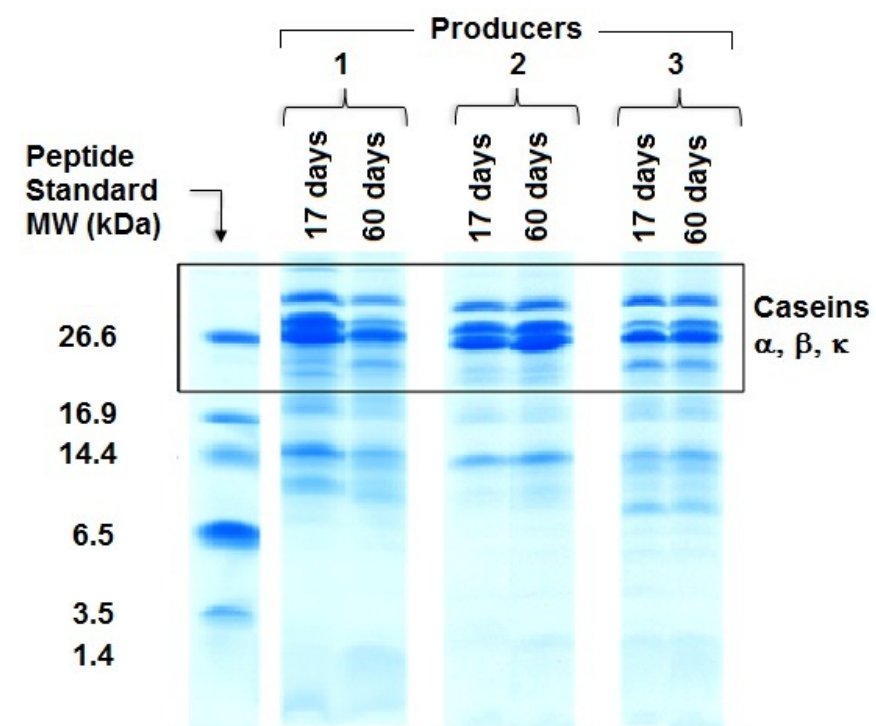

Fig. 3 Tricine-SDS-PAGE electrophoretic profiles of defatted protein-peptide extracts obtained from artisanal cheeses of three different producers $(1,2$ and 3$)$. 
in cheese. These results refer to the genomic analysis, monitoring of transcriptional mechanism activity of genes [10], proton transverse of water/oil relaxation $[11,12]$ and immunochemical quantification of milk proteins [9], respectively. The disadvantage of the above-mentioned methods is related to the need for a large financial investment in equipment acquisition [7, 10-12] when compared to the Tricine-SDS-PAGE electrophoresis method. Another scientific group working with soybean proteins has also used Tricine-SDS-PAGE method, however a complicate and long time for pure extracted was utilized [13]. Moreover, the electrophoretic analysis utilized in this paper has three advantages: (a) detection of protein breakdown and peptide formationin the same gel; (b) simple and alternative method of defatting; (c) micro-quantities utilization of reagent and sample. The excellent result obtained can be observed in Fig. 3. A total integrity of the three caseins $(\alpha, \beta$ and $\kappa)$ and no appearance of peptides were observed in the peptide/protein extracts. The lack of casein hydrolysis can be observed by the high staining in the two different days of maturation $(17 \mathrm{~d}$ and $30 \mathrm{~d})$ of the cheese obtained from producer 2 (Fig. 3). In the cheese produced by producers 1 and 3 it was observed a reduction of staining of casein only after $60 \mathrm{~d}$ of maturation for producer 1 and for $17 \mathrm{~d}$ and $60 \mathrm{~d}$ for producer 3 (Fig. 3). Concerning peptide production, cheese of producer 1 has shown $11 \mathrm{kDa}$ peptide (17 d) and $9 \mathrm{kDa}$ peptide $(60 \mathrm{~d})$, in Fig. 3. The fingerprint variations among the producers show the need for standardization of the maturation process. Concerning the field of cheese production, it can be suggested that gel electrophoresis can serve as a database of images that together with process data will guarantee the quality of the cheeses. Regarding the methodological aspects, the utilization of micro-quantities of reagents and the simple procedure for fat removal are advantages concerning economic aspects and environmental preservation. Finally, this pilot study with artisanal cheese shows that utilization of this method could be applied in the future to characterize the quality of all sorts of cheeses. The most important advantage of this work isthe simplicity of the method of sample preparation together with the utilization of micro-quantities amounts of samples and reagents, when compared with other methodologies, chromatographic, electrophoretic, genomic and immunochemical [7-10].

\section{Conclusions}

This paper shows a contribution in the adjustment of a methodology of low cost for simultaneous analysis of protein and peptides using electrophoretic Tricine-SDS-PAGE as analytical tool. This contribution is related to low quantities of reagents and samples utilized for protein and peptide extraction and by the fast and simple procedure of defatting. This methodology may be useful for standardization and guarantee the quality of the cheese either by visualization of the diminishing of caseins content or by the appearance of new peptide, as a consequence of hydrolysis.

\section{References}

[1] Fox, P. F., Mcsweeney, P. L. H., Cogan, T. M., and Guinee, T. P. 2004. "Cheese: An Overview." In Cheese: Chemistry, Physics and Microbiology, 3th ed. London: Elsevier Academic Press.

[2] Silva, R. A., Bezerra, V. S., Pimentel, M. C., Porto, A. L., and Cavalcanti, M. T. 2016. "Proteomic and Peptidomic Profiling of Brazilian Antisanal 'Coalho' Cheese." Journal of the Science of Food and Agriculture 96: 4297-632.

[3] Taivosalo, A., Krisciunaite, T., Seiman, A., Part, N., Stulova, I., and Vilu, R. 2018. "Comprehensive Analysis of Proteolysis during 8 Months of Ripening of High-Cooked Old Saare Cheese." Journal of Dairy Science 101: 944-67.

[4] Laemmli, U. K. 1970. "Cleavage of Structural Proteins during the Assembly of the Head of Bacteriophage T4." Nature 227: 680-5.

[5] Arndt, C., Koristka, S., Bartsch, H., and Bachmann, M. 2012. "Native Polyacrylamide Gels." Methods Molecular Biology 869: 49-53.

[6] Schägger, H., and Jagow, G. V. 1987. "Tricine-Sodium 
Dodecyl-Polyacrylamide Gel Electrophoresis for the Separation of Proteins in the Range from 1 to $100 \mathrm{kDa}$." Analytical Biochemistry 166: 368-79.

[7] Lim, C. W., Lai, K. Y., Ho, W. T., and Chan, S. H. C. 2019. "Isotopic Dilution Assay Development of Nisin A in Cream Cheese, Mascarpone, Processed Cheese and Ripened Cheese by LC-MS/MS Method." Food Chemistry 292: 58-65.

[8] Vélez, M. A., Hynes, E. R., Rodriguez, G., Garitta, L., Wolf, I. V., and Perotti, M. C. 2019. "A New Technological Approach for Ripening Acceleration in Cooked Cheeses: Homogenization, Cooking and Washing of the Curd." WLT-Food Science and Technology 112: 108-241.

[9] Ivens, K, Baumert, J. L., Hutkins, R. L., and Taylor, S. L. 2016. "Effect of Proteolysis during Cheddar Cheese Aging on the Detection of Milk Protein Residues by ELISA.” Journal of Dairy Science 100: 1629-39.
[10] Pangallo, D., Kraková, L., Puskárová, A., Soltys, K., Bucková, M., Korenová, J., Budis, J., and Kuchta, T. 2019. "Transcription Activity of Lactic Acid Proteolysis-Related Genes during Cheese Maturation." Food Microbiology 82: 416-25.

[11] Chen, Y., Macnaughtan, W., Jones, P., Yang, Q., and Foster, T. 2020. "The State of Water and Fat during the Maturation of Cheddar Cheese." Food Chemistry 303: 125390.

[12] Everett, D. W., and Auty, M. A. E. 2017. "Cheese Microstructure." In Cheese: Chemistry, Physics and Microbiology, 4th ed., edited by Mc Sweeney, P. L., Fox, P. D., Cotter, D. W. London: Academica Press, 549.

[13] Ying, Y., Zhao, L., Kong, L., Kong, X., Hua, Y., and Chen, Y. 2015. "Solubilization of Proteins in Extracted Oil Bodies by SDS: A Simple and Efficient Protein Sample Preparation Method for Tricine-SDS-PAGE." Food Chemistry 181: 179-85. 